\title{
No walking away
}

\section{Leaving the European Union could be detrimental for science and innovation in the United Kingdom.}

Victory at the recent UK parliamentary election by the Conservative party, led by David Cameron, has posed serious questions about the future role of the country in the EU. Discontent with the perceived power of the European Commission and parliament has risen substantially across several countries in the past few years. In the UK, anti-EU campaigners feel that the European Commission imposes excessive rules and regulations; they worry about high levels of immigration, especially from eastern European countries, due to freedom of movement; and they believe that the EU charges billions for membership and the UK gets little in return. Cameron himself is already at work to negotiate a more independent role for the UK within the EU. Furthermore, keeping faith with a pledge made before the election, the new government will hold a referendum by the end of 2017 in which UK citizens will be able to decide whether the country should remain a member of the EU.

The possibility of leaving the EU has already raised significant concerns in sections of the scientific community. On 22 May, under the lead of an organization called Scientists for EU, a number of scientists including Nobel laureate Paul Nurse, the president of the Science Council Tom Blundell and the Astronomer Royal Martin Rees, signed an open letter to the minister of science and education, urging him to clearly communicate to the government and the public the benefits to science of staying in the EU.

The principal benefit is simply being part of an organization with a long tradition of supporting science and innovation. Since 1984, the Framework Programme of the European Commission has funded large collaborations among research groups spread around the continent. This was replaced in 2013 by Horizon 2020, which will look to expand this remit with a budget of $€ 67$ billion for the period up to the year 2020. Furthermore, the European Research Council, established in 2007, funds ambitious projects from individual researchers for several years. (As well as funding, the EU has played a strong role in defining regulations on the safe use of materials, which is of

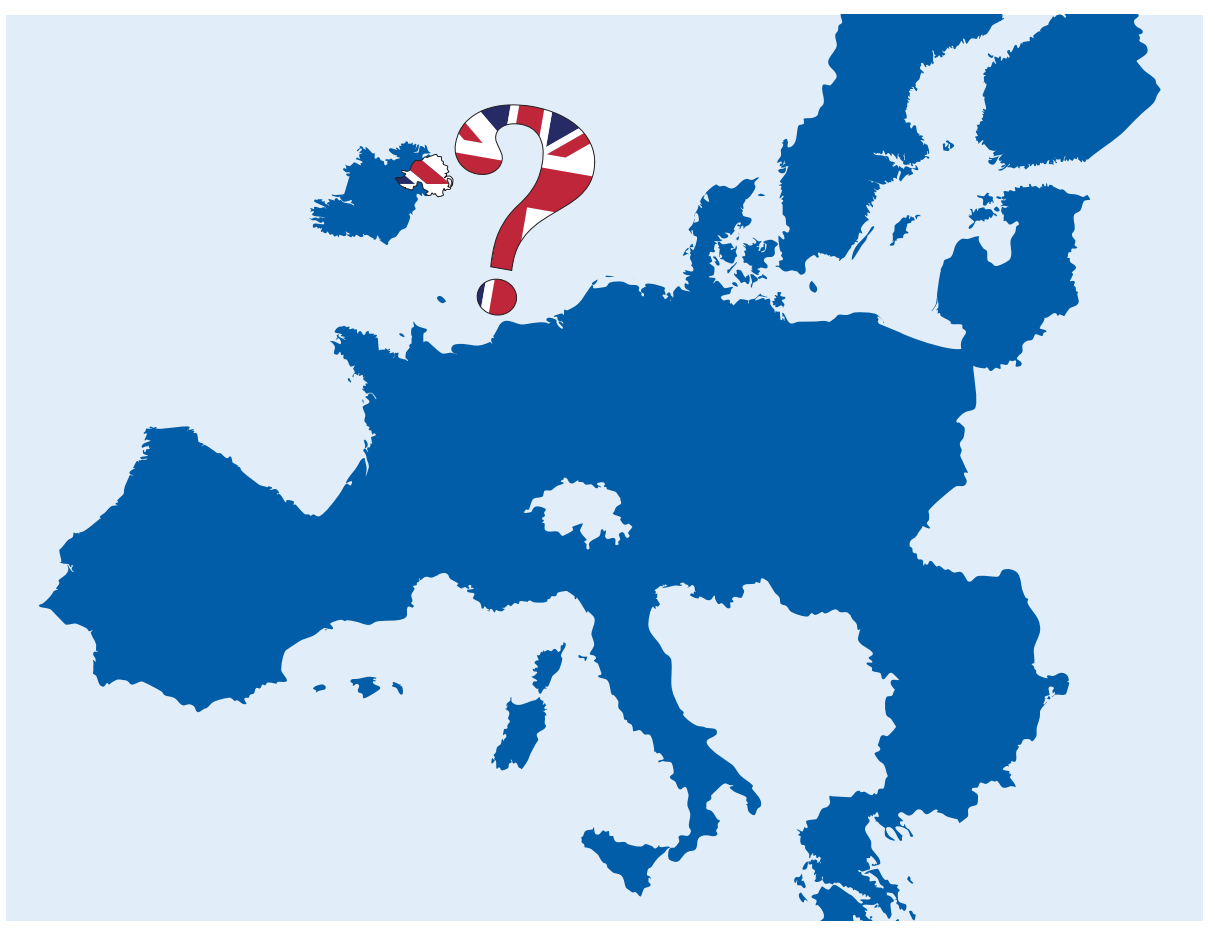

particular relevance to the development of nanotechnology.)

The UK has, until now, fared well in accessing this EU funding. For example, the country ranked second only to Germany in funding received during Framework Programme 7 (2007-2013), with $€ 6.9$ billion of a total budget of $€ 58.8$ billion. Out of just under 5,000 individual grants awarded by the European Research Council since 2007, about 1,100 have gone to scientists working in the $\mathrm{UK}$, which is impressive especially when compared with countries such as Germany and France who were awarded around 750 and 650 grants, respectively.

Beyond funding, UK science benefits considerably from freedom of movement. While the UK has a long tradition of hosting foreign scientists, which extends back before their membership of the EU, the free movement of EU citizens has made things notably simpler. Labs in the UK are often very international and contain a significant proportion of scientists and students from EU countries.

Freedom of movement is also important for the numerous technological start-up companies in the UK, which look to translate scientific results into commercial products and hire a considerable number of staff from other EU countries. For these companies, the opportunity to interact with international clients with minimal bureaucratic barriers and to move goods easily across the continent is of immense advantage, and could be lost by leaving the EU.

It could be argued that very little will actually change for UK science if the country left the EU. After all, universities in Switzerland, which is not a member of the EU, are full of scientists from across Europe and have access to EU funding. However, Switzerland's recent referendum on capping immigration may affect the degree to which Switzerland can access funding from the Horizon 2020 programme.

At this stage, there are numerous open questions about what would happen if the UK leaves. How easy will it be, for example, for EU scientists to come and work in the UK? Will access to funding remain the same? Will technological start-ups be pushed abroad? It seems clear, however, that leaving is unlikely to have a positive effect on science in the UK. 